OECDpublishing

\title{
REVIEW OF NATIONAL POLICY INITIATIVES IN SUPPORT OF DIGITAL AND AI-DRIVEN INNOVATION
}

OECD SCIENCE, TECHNOLOGY AND INDUSTRY POLICY PAPERS

October 2019 No. 79 
This paper was approved and declassified by written procedure by the Committee for Scientific and Technological Policy (CSTP) on 15 September 2019 and prepared for publication by the OECD Secretariat.

Note to Delegations:

This document is also available on ONE M\&P under the reference code:

DSTI/STP/TIP(2019)4/FINAL

This document, as well as any data and any map included herein, are without prejudice to the status of or sovereignty over any territory, to the delimitation of international frontiers and boundaries and to the name of any territory, city or area.

(C) OECD 2019

You can copy, download or print OECD content for your own use, and you can include excerpts from OECD publications, databases and multimedia products in your own documents, presentations, blogs, websites and teaching materials, provided that suitable acknowledgment of OECD as source and copyright owner is given. All requests for commercial use and translation rights should be submitted to rights@oecd.org. 


\section{Review of national policy initiatives in support of digital and AI-driven innovation}

Caroline Paunov*, Sandra Planes-Satorra* and Greta Ravelli*

\section{ABSTRACT}

What can we learn from new policies implemented in different OECD countries to foster digital and AI-driven innovation? This document reviews and extracts lessons from 12 national policy initiatives (four AI strategies and eight policy programmes) aimed at supporting breakthrough digital and AI-driven innovation and the application of those innovations by industry. Most selected policy initiatives actively involve multiple stakeholders from public research, industry and government, have mixed public-private funding models and seek international co-operation on AI. AI and digital research and innovation centres encourage interdisciplinarity, reduce hierarchies within centres and increase the autonomy of staff to enhance centres' agility and spur creativity. AI strategies set specific actions to strengthen AI research and capabilities, support business adoption of AI and develop standards for the ethical use of AI. Responsible data-access and sharing regulations, infrastructure investments, and measures to ensure that AI contributes to sustainable and inclusive growth are other priorities.

Keywords: innovation policy, digital innovation, digital technologies, artificial intelligence strategies

JEL codes: O30, O31, O33, O38, O25, I28

Acknowledgements: This work is part of an OECD benchmark analysis which has been financed and commissioned upon request of the French Surveillance committee of investments for the future (Comite de surveillance des investissements d'avenir), in the context of the evaluation of the first phase of the Programme d'investissements d'avenir (PIA). The benchmark study is presented as a series of six monographs. Each monograph provides examples of research, development, and innovation policies, organised by topic of relevance to the PIA. This document presents the first monograph, Enhancing digital innovation: Overview of different national policy initiatives. It reviews 12 innovation policy initiatives from different OECD countries aiming to support digital and data-driven innovation. The initiatives include eight digital innovation policy programmes and four artificial intelligence strategies. The detailed case studies can be found at https://community.oecd.org/community/cstp

The authors would also like to thank the delegates to the OECD Working Party on Innovation and Technology Policy for their comments.

* OECD 


\section{Table of contents}

Review of national policy initiatives in support of digital and AI-driven innovation 3

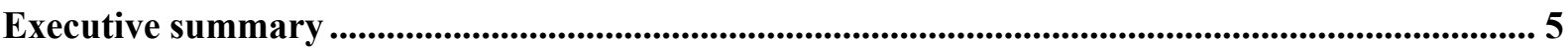

1. Cross-cutting lessons from case studies.............................................................................................. 8

2. Common characteristics of the 12 policy initiatives ............................................................................. 10

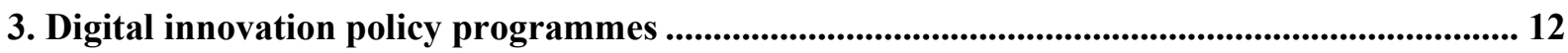

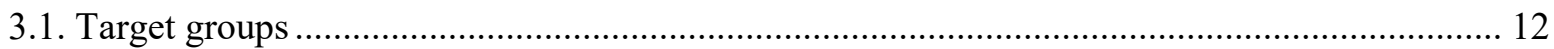

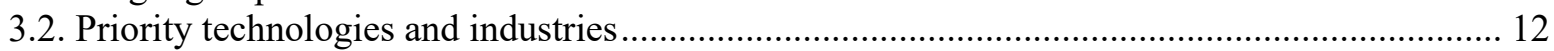

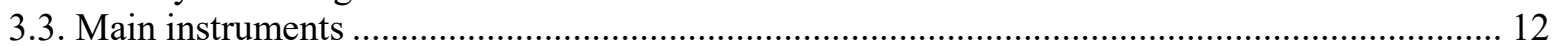

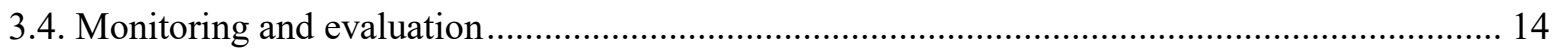

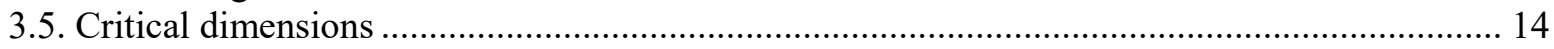

4. Artificial intelligence strategies ............................................................................................................. 16

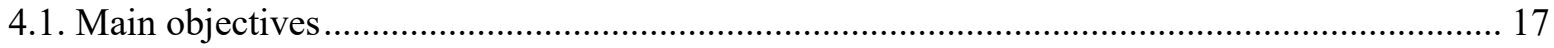

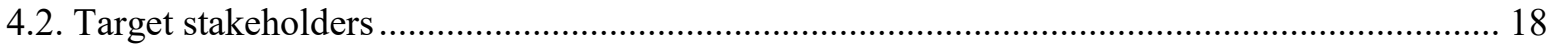

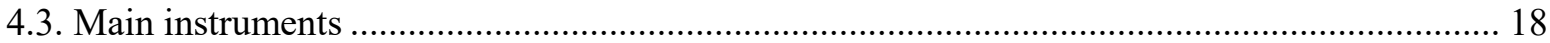

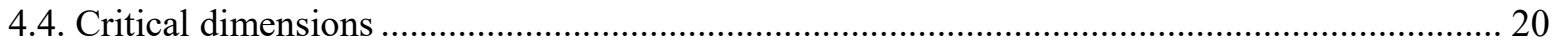

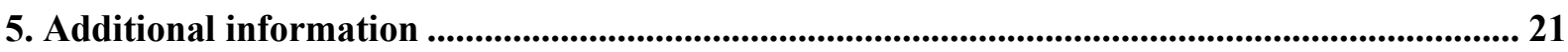

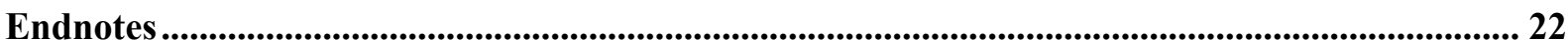

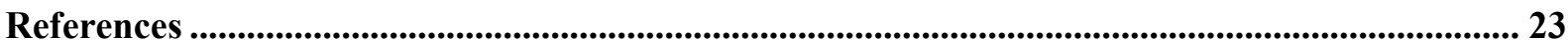




\section{Executive summary}

Digital technologies are changing innovation process and outcomes in practically all economic sectors of activity. Data are becoming a key input to innovation, enabling not only new products and services but also completely new business models; innovation cycles are accelerating, with virtual simulation, 3D printing and other digital technologies providing opportunities for more experimentation and versioning; and innovation processes are increasingly collaborative, given the growing complexity of and interdisciplinary needs for digital innovation. In this rapidly changing context, the competitiveness of different industries largely depends on their capacity to engage in digital innovation. How are countries encouraging breakthrough innovation in digital fields such as AI? How are they supporting the digital transformation in sectors of relevance for their national economy?

This document reviews and extracts lessons from 12 national policy initiatives (4 artificial intelligence strategies and 8 policy programmes) from Australia (CSIRO's Data61), Austria (Plattform Industrie 4.0), Canada (Pan-Canadian AI Strategy), Denmark (MADE Digital), the European Union (EU Strategy for Artificial Intelligence), Germany (Digital Hub Initiative and the German AI Strategy), Ireland (the National Digital Research Centre), the Netherlands (Smart Industry Field Labs), Sweden (AI Innovation of Sweden), the United Kingdom (Digital Catapult and the AI Sector Deal). These initiatives specifically aim to support breakthrough innovation as well as the development of new digital technology applications for industry. The study excludes initiatives that support the deployment of existing digital technologies.

The 12 selected policy initiatives share some features:

- They are all fairly young - 10 out of 12 have been adopted in the last 5 years with impacts to be reaped in the future.

- While governments have mostly initiated the programmes, the private sector has often been closely involved in programme design from the inception stage and also often contributes financial resources.

- Most of the initiatives are concerned with promoting the inclusion of different national regions in digital and AI-driven innovation. For instance, all four AI strategies involve the establishment of regional centres for AI research.

- Many initiatives seek to establish international co-operation to access a pool of talent or expertise that may not be (sufficiently) available nationally and to allow local institutions to connect to top research and innovation networks, which is critical for those working on emerging technology areas (e.g. AI) to remain at the cutting-edge.

\section{Digital innovation policy programmes}

The eight selected policy programmes support innovation in a range of emerging technologies that matter specifically to the most important national industries. For example, the Dutch Smart Industry Field Labs and the Danish MADE Digital initiative focus on Industry 4.0 technologies (e.g. IoT, robotics, 3D printing, digital visualisation) that are 
particularly relevant to domestic manufacturing firms. The German Digital Hub Initiative also focuses on technologies and sectors reflecting regional industrial strengths (e.g. health, logistics, finance, insurance). In the United Kingdom, Digital Catapult focuses on emerging technologies (e.g. AI, robotics, future networks and augmented reality) to answer the needs of creative industries, one of the country's fastest-growing sectors.

The policy programmes use - and often combine - diverse policy instruments for i) new technologies' adoption and diffusion, ii) co-operation and iii) digital entrepreneurship. First, instruments to support digital technology adoption and diffusion include testing facilities such as those of the Smart Industry Field lab 'Campione' (the Netherlands) where innovators in chemical industry can experiment with predictive maintenance systems, based on advanced sensors and data analytics. Second, instruments to facilitate cooperation and open digital innovation include collaborative innovation labs (e.g. AI Innovation in Sweden), open innovation tools (e.g. the Expert Connect Database of CSIRO's Data61 in Australia) and match-making and networking events (e.g. the pit-stop events organised by Digital Catapult in the United Kingdom). Third, instruments to support digital entrepreneurship include accelerator programmes for early-stage businesses (the LaunchPad accelerator of NDRC in Ireland) as well as access to expertise and advanced infrastructures for start-ups (e.g. Digital Catapult's Machine Intelligence Garage).

Most initiatives encourage interdisciplinary research and co-operation among different institutions (notably research and industry). For instance, the Digital Catapult is organised around multi-functional teams of technologists, business specialists, product managers, and policy and innovation experts; the German Digital Hub Initiative emphasises the exchange of cross-sectoral expertise among different hubs across the country.

Innovative and less hierarchical organisational structures have also been adopted by a number of digital research and innovation centres to spur creativity and attract talent. CSIRO's Data61, for instance, has adopted a "start-up" culture with flatter organisational structures, less middle management and more autonomous staff. Smart Industry field labs also have decentralised structures and work along a project-based approach. Those centres also have mixed funding models that balance funding from public and private sources. This allows them to connect directly with industry needs and demands, while maintaining opportunities to focus on strategic areas of research and action from a wider societal perspective.

\section{Artificial intelligence strategies}

Most OECD countries have recently adopted or are working to develop strategies to maximize the economic and societal benefits of Artificial Intelligence (AI). This document explores those of Canada -the first country to adopt such a strategy in March 2017-, the European Union, Germany and the United Kingdom.

These AI strategies differ in terms of their stated objectives and relative weight given to each of those objectives. Common objectives across most AI strategies are: 1) strengthen research in AI, for example by creating new research centres or devoting specific funding to AI research programmes; 2) strengthen AI capabilities, for instance by creating AI master or $\mathrm{PhD}$ programmes and granting exceptional talent visas to attract international AI specialists; 3) support businesses in developing and adopting AI applications; and 4) develop standards for the ethical use of AI, for instance with the creation of expert councils or committees to explore the ethical, economic, societal and legal implications of AI. 
Some strategies also refer to the need to invest in specific infrastructures, develop responsible data-access and sharing regulations, enhance government use of AI, and ensure that AI creates positive impacts on inclusiveness and sustainable development. However the actions to implement these objectives are often less concrete. 


\section{Cross-cutting lessons from case studies}

This document describes and extracts lessons from 12 policy initiatives (4 artificial intelligence strategies and 8 policy programmes) from Australia, Austria, Canada, Denmark, Germany, Ireland, the United Kingdom, the Netherlands, Sweden and the European Union that support digital and data-driven innovation (Table 1).

These 12 initiatives primarily aim to enhance research and innovation in digital fields, including artificial intelligence (AI), the Internet of Things (IoT), augmented reality and blockchain technologies. They intend not only to generate more breakthrough innovations, but also to develop new applications for industry. These initiatives also have a strong collaborative component: they have involved multiple stakeholders from inception to implementation, and are mostly financed by both public and private funding. They focus on challenges similar to those addressed by the "research valorisation" and "industry modernisation" programmes under the French Investments for the Future Programme (Programme d'investissements d'avenir [PIA]). This study excludes initiatives that support the deployment of existing digital technologies.

The eight digital innovation programmes can be distinguished as follows. Four programmes are collaborative and multidisciplinary research and innovation centres for digital and datadriven research and co-creation: Data61 of the Commonwealth Scientific and Industrial Research Organisation (CSIRO) in Australia, Smart Industry field labs in the Netherlands, AI Innovation in Sweden and Digital Catapult in the United Kingdom. Two programmes support digital entrepreneurship: the Digital Hub Initiative in Germany and the National Digital Research Centre (NDRC) in Ireland. The seventh programme, Manufacturing Academy of Denmark (MADE) Digital, supports smart-industry research projects conducted jointly between firms, universities, and research and technology organisations (RTOs). The final programme, Plattform Industrie 4.0 in Austria, acts as a supportive policy co-ordination hub, facilitating dialogue among all stakeholders on the digital transformation of the country's industry.

The four AI strategies aim to enhance national AI capacities, boosting economic and social benefits from the diffusion of AI, and preventing possible risks associated with the application of AI. The selected cases studied here are the Pan-Canadian AI Strategy (Canada), the EU Strategy for Artificial Intelligence, ${ }^{1}$ the German AI Strategy and the AI Sector Deal (United Kingdom). The strategies exemplify the widespread adoption of AI strategies across the OECD (see Figure 1), adopting different but related approaches. While the Canadian strategy focuses mainly on strengthening capabilities for AI research, the AI Sector Deal in the United Kingdom, developed jointly with industry, is unique in that it incorporates both government and industry commitments. Meanwhile, the EU and German strategies cover a wide variety of AI-related policy domains.

Through the selected programmes, this document highlights trends in how innovation policy initiatives address digital transformation objectives. It presents the rationales for these initiatives and the instruments used, the targeted sectors and technologies, the monitoring and evaluation procedures, and the main critical dimensions. 
Table 1. Selected case studies, by country and type of policy initiatives

\begin{tabular}{|c|c|c|c|}
\hline & Country & Type & Period \\
\hline \multicolumn{4}{|c|}{ Digital innovation policy programmes } \\
\hline Data61, CSIRO & Australia & $\begin{array}{l}\text { Research and } \\
\text { innovation centre }\end{array}$ & 2016-present \\
\hline$\frac{\text { Plattform }}{\text { Industrie } 4.0}$ & Austria & $\begin{array}{c}\text { Policy co-ordination } \\
\text { hub }\end{array}$ & 2015-present \\
\hline MADE Digital & Denmark & $\begin{array}{l}\text { Collaborative } \\
\text { research } \\
\text { programme }\end{array}$ & $2017-20$ \\
\hline
\end{tabular}

CSTO's Data61 is a research and

CSIRO's Data61 is a research and development (R\&D) organisation that conducts fundamental and applied research promoting data-driven innovation. It collaborates with other actors in Australia's innovation ecosystem.

Platform Industrie 4.0, a not-for-profit association, acts as a supportive policy co-ordination hub facilitating the process of digital transformation of industry in Austria by strengthening co-operation and dialogue among all stakeholders.

MADE Digital is a research and innovation programme promoting co-operation between large companies and small and medium-sized enterprises (SMEs), university research teams, and research and technology organisations to jointly develop and implement digital tailor-made solutions that address the specific needs of Danish manufacturing companies.

\begin{tabular}{|c|c|c|c|c|}
\hline$\frac{\text { The Digital Hub }}{\text { Initiative }}$ & Germany & $\begin{array}{l}\text { Support for digital } \\
\text { entrepreneurship }\end{array}$ & 2017-present & $\begin{array}{l}\text { The Digital Hub Initiative promotes digital innovation } \\
\text { in Germany by attracting digital start-ups to } 12 \text { cities } \\
\text { specialising in different sectors or technologies, } \\
\text { converting them in highly entrepreneurial innovation } \\
\text { hotspots. }\end{array}$ \\
\hline $\begin{array}{l}\frac{\text { National Digital }}{\text { Research Centre }} \\
\text { (NDRC) }\end{array}$ & Ireland & $\begin{array}{l}\text { Support for digital } \\
\text { entrepreneurship }\end{array}$ & 2007-present & $\begin{array}{l}\text { NDRC is a publicly funded early investor in digital } \\
\text { technology companies. It uses an accelerator model } \\
\text { that provides them with a wide range of support } \\
\text { services, and a modest amount of capital that } \\
\text { enables them to become more efficient and investor } \\
\text { ready. }\end{array}$ \\
\hline$\frac{\text { Smart Industry Field }}{\underline{\text { Labs }}}$ & $\begin{array}{l}\text { The } \\
\text { Netherlands }\end{array}$ & $\begin{array}{c}\text { Research and } \\
\text { innovation centres }\end{array}$ & 2014-present & $\begin{array}{l}\text { Smart Industry field labs are public-private } \\
\text { partnerships aiming to develop, test and implement } \\
\text { smart-industry solutions in the Netherlands. }\end{array}$ \\
\hline$\frac{\text { Al Innovation of }}{\text { Sweden }}$ & Sweden & $\begin{array}{l}\text { Research and } \\
\text { innovation centre }\end{array}$ & $2019-21$ & $\begin{array}{l}\text { Al Innovation of Sweden is a national centre for Al- } \\
\text { related research, innovation and education. It aims } \\
\text { to enhance research and adoption of Al. }\end{array}$ \\
\hline Digital Catapult & $\begin{array}{l}\text { United } \\
\text { Kingdom }\end{array}$ & $\begin{array}{l}\text { Research and } \\
\text { innovation centre }\end{array}$ & 2013-present & $\begin{array}{l}\text { Digital Catapult is a technology innovation centre } \\
\text { driving the early adoption of advanced digital } \\
\text { technologies. }\end{array}$ \\
\hline \multicolumn{5}{|l|}{ Al strategies } \\
\hline $\begin{array}{l}\text { Pan-Canadian } \\
\text { Al Strategy }\end{array}$ & Canada & Al research & 2017-present & $\begin{array}{l}\text { The Canadian strategy aims to enhance } \\
\text { breakthrough research and innovation in the field of } \\
\text { Al, notably by supporting a network of Al research } \\
\text { excellence centres, and attracting and retaining Al } \\
\text { talent. }\end{array}$ \\
\hline EU Strategy for Al & $\begin{array}{l}\text { European } \\
\text { Union }\end{array}$ & $\begin{array}{l}\text { Al research and } \\
\text { diffusion across the } \\
\text { economy }\end{array}$ & $2019-27$ & $\begin{array}{l}\text { The EU Strategy for Al aims to promote excellence } \\
\text { in AI research, leading not only to breakthrough } \\
\text { innovations, but also to the diffusion of Al } \\
\text { applications }\end{array}$ \\
\hline German Al Strategy & Germany & $\begin{array}{l}\text { Al research and } \\
\text { diffusion across the } \\
\text { economy }\end{array}$ & 2018-present & $\begin{array}{l}\text { This strategy aims to make Germany a leading } \\
\text { centre for Al by strengthening Al research and } \\
\text { talent, supporting the development and adoption of } \\
\text { Al by businesses, and taking actions to ensure Al } \\
\text { has positive impacts on society. }\end{array}$ \\
\hline$\underline{\text { Al Sector Deal }}$ & $\begin{array}{l}\text { United } \\
\text { Kingdom }\end{array}$ & $\begin{array}{l}\text { Al research and } \\
\text { diffusion across the } \\
\text { economy }\end{array}$ & $2017-28$ & $\begin{array}{l}\text { The Al Sector Deal sets a wide range of actions to } \\
\text { be undertaken by government as well as industry to } \\
\text { maximise the potential of Al in the United Kingdom. }\end{array}$ \\
\hline
\end{tabular}




\section{Common characteristics of the $\mathbf{1 2}$ policy initiatives}

The 12 initiatives presented in this report share the following features:

- The initiatives are fairly young. Ten out of 12 of these initiatives and strategies have been adopted in the last 5 years, meaning there has not been an opportunity to evaluate their impacts, beyond assessing programmes' internal functioning. In particular, evaluations of their effects on digital innovation have so far been rare.

- While governments have mostly initiated the programmes, the private sector has been involved in programme design from the inception stage. Eight of the 12 strategies and initiatives were established by ministries or national governmental agencies; the other 4 were initiated by academic or research institutions (i.e. NDRC in Ireland) and governments, jointly with industry (i.e. Plattform Industrie 4.0 in Austria, MADE Digital in Denmark and the AI Sector Deal in the United Kingdom).

- Funding often combines public resources with contributions from the private sector. All eight digital innovation policy programmes are funded by both public and private resources. For example, Digital Catapult in the United Kingdom obtains funding from three sources: business-funded R\&D contracts; publicly and privately funded contract research; and core public funding for infrastructure, expertise and skill development. Data61 (CSIRO) also has a funding model that combines public and private funding, as it both runs research projects for industry partners and conducts fundamental and self-directed research. Two rationales explain this mixed funding model. The first is that private-sector contributions may help expand programme activities and ensure that the private sector engages in the activity. The second, emphasised by Data61, is the importance of maintaining the highestpossible level of research standards, which may be facilitated by working with top expertise in the public sector and engaging in projects with industry partners.

Plattform Industrie 4.0 in Austria and AI Innovation in Sweden are also partly funded by industry membership fees. In Germany's Digital Hub Initiative, the public sector is funding the Hub Agency, while each digital hub is financed by the private sector and through its own innovation programmes. The budgets of all four AI strategies, particularly the UK AI Sector Deal, commit public resources but also explicitly solicit private-sector contributions.

- Regional inclusiveness is a key concern of several programmes. All four AI strategies present a marked regional dimension through the establishment of regional centres for AI research. For instance, the UK AI Sector Deal aims to strengthen AI clusters in Edinburgh, Belfast, Bristol and Cambridge, and to invest in new clusters to support the use of AI by businesses across the country. Four of the eight policy programmes (i.e. Plattform Industrie 4.0 in Austria, Smart Industry Field Labs in the Netherlands, the Digital Hub Initiative in Germany and Digital Catapult in the United Kingdom) also have strategies supporting regional development. The German and Dutch initiatives have an important geographic dimension, with 12 digital hubs across different regions of Germany and 41 smart industry field labs across the Netherlands. 
- International co-operation is explicitly integrated in the 12 initiatives. All of the initiatives emphasise the need to strengthen international partnerships in order to maximise impacts. Two main rationales explain this trend: on the one hand, international co-operation allows accessing a pool of talent or expertise that may not be (sufficiently) available nationally. On the other hand, international cooperation allows local institutions to connect to top research and innovation networks, which is critical for those working on emerging technology areas (e.g. AI) to remain at the cutting-edge. Depending on their characteristics, the initiatives promote co-operation with leading public research organisations (e.g. the research institutes supported by the Pan-Canadian AI Strategy collaborate with the French National Centre for Scientific Research [CNRS]) and/or private organisations around the world (e.g. Germany's Digital Hub Initiative encourages partnerships between digital start-ups and leading international companies, such as Hewlett-Packard). Digital Catapult in the United Kingdom and Data61 in Australia also participate in international research co-operation projects.

AI strategies also have an international component. For example, international expert groups have been created to advise on especially sensitive areas (e.g. ethical considerations and data regulations). Moreover, measures have been taken to attract international AI talent to national research organisations and businesses (e.g. special visas for international talent in the United Kingdom). 


\section{Digital innovation policy programmes}

This section presents the main characteristics of the eight digital innovation policy programmes mentioned above. It identifies common trends and highlights their most innovative aspects.

\subsection{Target groups}

Six of the eight programmes have broad coverage, targeting private companies (including start-ups, SMEs and large companies), the public sector, universities and research institutes. Two of them (MADE Digital in Denmark and the Smart Industry Field Labs in the Netherlands) target research co-operation among different actors.

The two remaining programmes (NDRC in Ireland and the Digital Hub Initiative in Germany) specifically target technology start-ups, investors, SMEs and other firms.

\subsection{Priority technologies and industries}

The policy programmes focus on a diverse set of emerging technologies that are especially important to the respective national economies, and thus directly or indirectly target specific industries. For example, the Dutch Smart Industry Field Labs and the Danish MADE Digital initiative focus on Industry 4.0 technologies (e.g. IoT, robotics, 3D printing, digital visualisation) that are particularly relevant to domestic manufacturing firms. The German Digital Hub Initiative also focuses on technologies and sectors reflecting regional strengths (e.g. health, logistics, finance, insurance). In the United Kingdom, Digital Catapult focuses on emerging technologies (e.g. AI, robotics, future networks and augmented reality) to answer the needs of creative industries - one of the country's fastest-growing sectors, accounting for an important share of total employment and service exports. In Australia, CSIRO's Data61 does not specifically target any sector, but its engagement in collaborative or industry-contracted research ensures the relevance of its research to industry.

Practically all of the initiatives target and implement different approaches to supporting breakthrough research and innovation. The Digital Hub Initiative in Germany aims to recreate highly entrepreneurial ecosystems (such as Silicon Valley) in specific locations. AI Innovation of Sweden aims to develop methods and infrastructures to gather large quantities of data (including those donated, acquired and developed internally) to become an international hub for AI research and innovation. Digital Catapult in the United Kingdom provides start-ups with access to key infrastructure (e.g. augmented-reality labs, high-capacity computing) and expertise to facilitate the development of new advanced digital solutions. Finally, CSIRO's Data61 in Australia encourages researchers to undertake risky research with more disruptive potential.

\subsection{Main instruments}

The programmes use - and often combine - diverse innovative policy instruments. Those identified can be divided into three groups: 


\section{diffusion:}

\section{(1) Policy instruments to support digital technology adoption and}

- Testing facilities: Digital Catapult in the United Kingdom provides several infrastructures to enable prototyping and demonstrating new technologies (e.g. the Dimension Studio facilitates firms' access to immersive production facilities for virtual and augmented reality software [including games], and the Things Connected project allows experimenting with and prototyping new IoT products and services). Most Smart Industry field labs in the Netherlands also provide such spaces. For instance, the Campione field lab provides a facility where innovators in chemical and process industry can experiment with predictive maintenance systems, based on advanced sensors and data analytics.

- Business advisory services: The Austrian Maturity Model, developed by Plattform Industrie 4.0 together with Business Upper Austria and the University of Applied Science Upper Austria, offers an independent evaluation of firms' digital readiness through a technology-neutral assessment. With the Inventorium toolkit, NDRC in Ireland provides start-ups with methods and processes for building collaborations and business propositions.

\section{(2) Instruments to facilitate co-operation and open digital innovation:}

- Collaborative innovation labs: Smart Industry field labs in the Netherlands, MADE Digital in Denmark and AI Innovation in Sweden all provide physical and digital spaces where science and industry researchers can co-operate and co-create. The services provided include access to prototyping and testing facilities, meeting spaces for researchers, and infrastructures to share and exploit large amounts of data.

- Open innovation tools: CSIRO's Data61 in Australia created the Expert Connect Database, containing the profiles of 45000 research and engineering experts from Australian research organisations, to facilitate co-operation between industry and researchers. The organisation also created the National Map, a visualisation and access tool for open government data that gathers spatial data from different Australian government agencies in an easily searchable database, to be used in research projects.

- Matchmaking and networking events: Several programmes focus on bringing together different actors of the digital innovation ecosystem. The goal is to promote research co-operation, facilitate funding for digital-technology research ideas by matching funding institutions to new digital ventures, and drive the commercialisation of digital innovations. Digital Catapult in the United Kingdom organises pit-stop events, where start-ups pitch their business proposals to potential partners, clients and investors. In Ireland, NDRC organises "Open Night" networking events for start-ups and potential investors.

\section{(3) Instruments to support digital entrepreneurship:}

- Accelerator programmes for early-stage businesses: the LaunchPad accelerator of NDRC in Ireland offers digital entrepreneurs a 12-week training and mentoring programme. In Germany, several hubs within the Digital Hub Initiative provide trainings and expertise to start-ups: in Munich, for example, the InsurTech Hub's two-month W1 Forward InsurTech Accelerator Programme targets early-stage 
start-ups wanting to make an impact on the insurance business with their digital solutions. It provides them with workshops, mentoring and coaching sessions to help them become experts in insurance who are ready to build pilots with corporate members.

- Access to expertise and advanced infrastructures for start-ups: in the United Kingdom, Digital Catapult's Machine Intelligence Garage helps early-stage AI companies access computational power and expertise so that they can develop new machine-learning and AI solutions. Digital Catapult's 12-week Augmentator programme supports early-stage businesses in developing innovative and commercially focused applications of augmented reality. In Ireland, the NDRC Catalyser programme provides access to technological expertise for start-ups with a business idea targeting an unmet market need. Start-ups engaging in those trainings are often offered customised mentoring by experts.

Finally, instruments supporting policy making in the digital age include evidence-based analyses and strategies. In Australia, CSIRO's Data61 developed several analytical reports aimed at business and government decision makers, including Distributed Ledgers: Scenarios for the Australian economy over the coming decades, and Risks and opportunities for systems using blockchain and smart contracts (Hanson, Reeson and Staples, 2017 $[1]$; Staples et al., 2017 $[2]$ ). In Austria, Plattform Industrie 4.0 published Qualification and Competences for Industry 4.0 (Industrie 4.0 Österreich, 2018 ${ }_{[3]}$ ). This strategy paper compiles 81 recommendations in 7 fields of action at 5 levels (general recommendations, school, initial vocational training, tertiary education and continuous training), building on the available evidence on drivers of - and barriers to - the digital transformation.

\subsection{Monitoring and evaluation}

Monitoring and evaluation of programmes have generally been conducted by external institutions, but also sometimes by the programmes themselves. Data61 (CSIRO) conducts its own Impact Framework, which requires each team to identify the world-leading groups in its domain, and compare realistically their methods, outcomes and strategy with its own. NDRC publishes an annual report on its activities and achievements, particularly the number of start-ups in which it invested and the resulting job creation. In 2017, NDRC estimated that $29 \%$ of companies in which it invested had women in their founding team and found that such start-ups were more likely to secure follow-on investments. The Smart Industry field labs have also monitored their performance by using indicators to track their achievements, particularly the number of projects conducted, the number of university students and $\mathrm{PhDs}$ engaged in each lab, and the number of indirect jobs and spinoffs created. In 2016-18, each field lab engaged on average in 8 projects, 5 field labs generated an average of 79 indirect jobs, and 5 field labs created spinoffs. Plattform Industrie 4.0, the Digital Hub Initiative and MADE Digital have not yet evaluated their impact.

\subsection{Critical dimensions}

The critical dimensions of these projects include:

- Interdisciplinarity and co-operation among different institutions (notably research and industry) are highlighted in several initiatives. Australia's Data61 comprises research groups that combine expertise in data analytics with specific domain expertise. The UK Digital Catapult is organised around multi-functional teams of technologists; 
business specialists; product managers; and policy, research and innovation experts. The Dutch Smart Industry field labs support interdisciplinary research and co-operation with a range of partners from industry, research, civil society and government. Finally, the German Digital Hub Initiative emphasises the exchange of cross-sectoral expertise among different hubs across the country.

- Innovative and less hierarchical organisational structures have also been adopted to spur creativity and attract talent in digital research and innovation centres. CSIRO's Data61, for instance, has adopted a "start-up" culture with flatter organisational structures, less middle management and more autonomous staff. Research leaders are also encouraged to take risks and experiment with new ideas. Smart Industry field labs also have decentralised structures and work along a project-based approach.

- Mixed funding models that balance funding from public and private sources is a key dimension of many of these initiatives. In the case of research centres, such approaches allow them to connect directly with industry needs and demands, while maintaining opportunities to focus on strategic areas of research and action from a wider societal perspective. Industry funding also allows projects to reach a larger scale and to potentially initiate projects that industry will steer in the future when public funding is applied elsewhere. 


\section{Artificial intelligence strategies}

New policy strategies (i.e. strategies or plans setting the vision, priorities and general guidelines for policy action) have been developed around the world to respond to the new challenges of the digital age. Many countries have recently launched national AI strategies, spurred by the possibly far-reaching implications of AI for the economy and society. The AI strategies often complement their main science, technology and innovation strategy, but are also used alongside other digital or technology-specific strategies (e.g. Germany is preparing its blockchain strategy) (Figure 1).

This section describes the main objectives and characteristics of four selected AI strategies: the Pan-Canadian AI Strategy, the EU Strategy for AI, the German AI Strategy and the AI Sector Deal (United Kingdom).

Figure 1. Timeline of national adoption of AI strategies

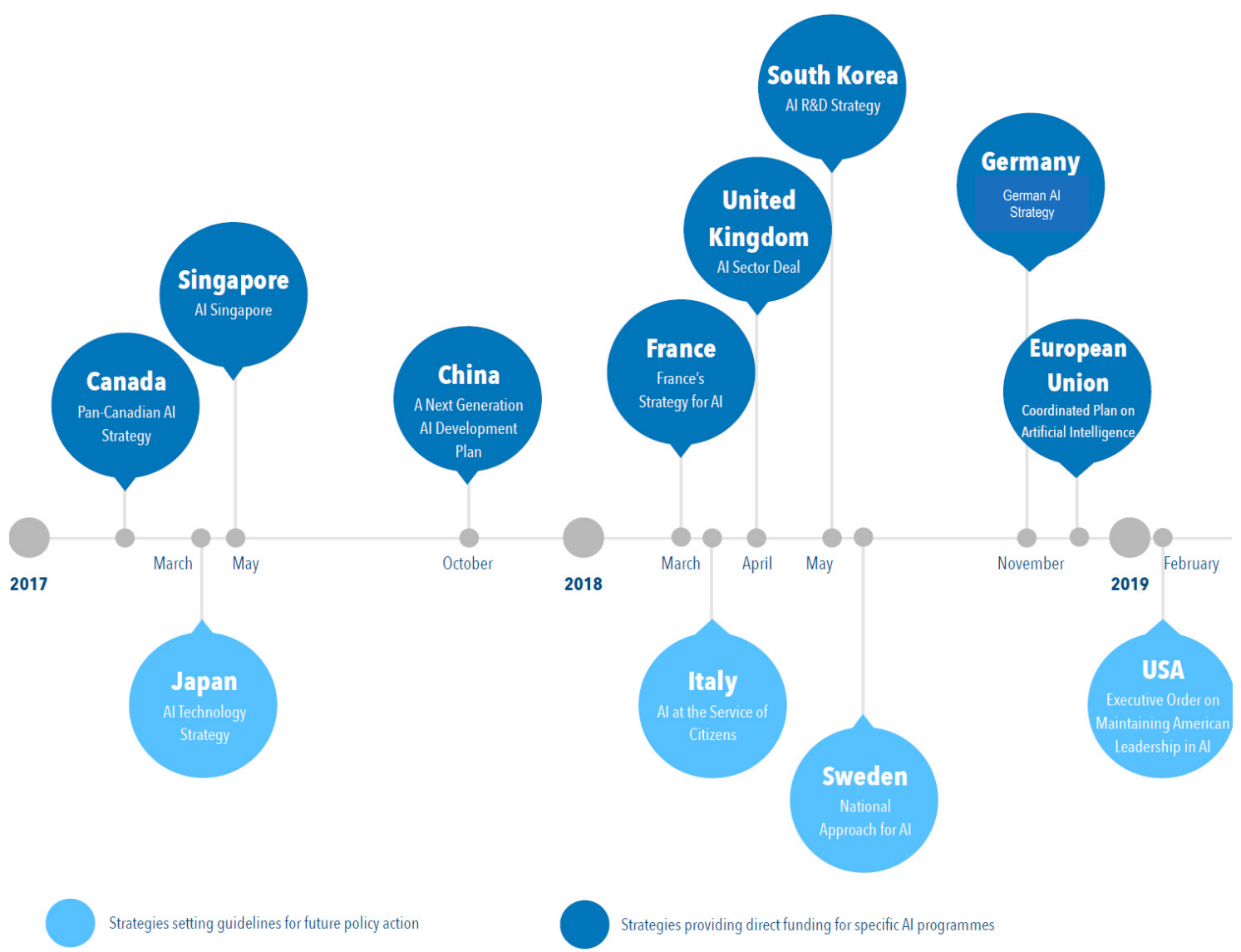

Source: Planes-Satorra and Paunov (2019[4]). 


\subsection{Main objectives}

AI strategies differ in terms of their stated objectives and the relative weight given to each objective (Dutton, Barron and Boskovic, 2018 $8_{[5]}$; Planes-Satorra and Paunov, 2019 $9_{[4]}$ ). The common objectives across most AI strategies are as follows:

- Strengthen research in AI. This can be done by creating new research centres or devoting specific funding to AI research programmes. The AI strategies of Canada and Germany particularly emphasise becoming international leaders in AI research. The Pan-Canadian AI Strategy, for example, commits funding to three centres of excellence in AI research and innovation (located in Edmonton, Montreal and Toronto) in order to build a leading AI research network.

- Strengthen AI capabilities. All strategies emphasise the relevance of attracting, retaining and training domestic and international AI talent, e.g. by creating master's or PhD programmes in AI. The AI Sector Deal in the United Kingdom supports AI fellowship programmes, government-funded $\mathrm{PhDs}$ and industry-funded master's degrees. It aims to build 200 new doctoral studentships every year in AI and related disciplines by 2020, and to have at least 1000 government-supported $\mathrm{PhD}$ places by 2025 . It also aims to grant 2000 "exceptional talent" visas every year to attract international talent, including AI specialists. France and Canada have also created AI programmes to attract and retain top researchers, as well as train young researchers.

Some strategies, such as the German AI strategy and the French Strategy for Artificial Intelligence, also address the need to help individuals develop new skills for the digital age. For example, the provision of vocational or retraining programmes (e.g. to facilitate human-machine interactions) aims to improve future working conditions in the context of increased automation.

- Support businesses in developing and adopting AI applications. This is done, for instance, by providing specific funding for AI start-ups and SMEs. The AI Sector Deal in the United Kingdom has adopted measures to diffuse AI, e.g. by investing in high-potential AI businesses through the Industrial Strategy Challenge Fund competition and the British Business Bank's venture capital programmes. The EU Strategy for AI aims to establish testing facilities to allow experimenting stateof-the-art technologies in real-world environments. It also aims to create Digital Innovation Hubs (DIHs) across Europe to spur the private and public sectors to adopt AI. In particular, these hubs would help companies (including SMEs) identify necessary data sets, develop algorithms and train professionals to use AI solutions.

- Develop standards for the ethical use of AI. A common approach is to create expert councils or committees, and fund projects that ensure the ethical and transparent development of AI. The French Strategy for AI develops an ethical framework through a group of international independent experts, following the model of the Intergovernmental Panel on Climate Change. The German AI Strategy establishes an AI Observatory to ensure sustainable development of AI, and to initiate European and transatlantic dialogue on human-centred use of AI in the world of work. The Pan-Canadian AI Strategy funds "AI \& Society Workshops", convening international experts to explore the ethical, economic, societal and legal implications of AI.

Less common objectives discussed in AI strategies include: 
- Support investments in infrastructure for AI. Some strategies highlight the need to invest in specific infrastructure for AI, such as research centres (e.g. the Canadian strategy), AI testing and experimentation infrastructures, as well as telecommunications infrastructure (5G mobile networks, fibre broadband). The EU strategy also stresses the need to invest in high-performance computing, quantum technologies and the cloud.

- Support responsible data access and sharing. The AI strategies of France, the European Union and the United Kingdom introduce policy actions pertaining to data access, including incentives for opening data, privacy protection and cybersecurity. The UK AI Sector Deal aims to establish fair, equitable and secure data-sharing frameworks, such as data trusts - mechanisms where parties have defined rights and responsibilities regarding shared data. The strategy also establishes the creation of a Centre for Data Ethics and Innovation, an advisory body that will identify the necessary measures to strengthen and improve the use of data and AI. The French Strategy for AI takes a similar approach: it promotes the creation of sector-specific platforms to compile and share data, provide access to large-scale computing infrastructures suitable for AI and facilitate experimentation in controlled environments.

- Support AI to achieve inclusiveness and sustainable development. France, Germany and the United Kingdom incorporate specific inclusion objectives in their AI strategies to ensure a diverse AI talent pool, particularly by encouraging the participation of women and minority groups, and promoting the use of AI applications to drive social inclusion. German AI Strategy supports broad societal dialogue around AI issues and provides funding to develop innovative AI applications that support social inclusion and cultural participation, and benefit the environment. Similarly, the French Strategy for AI supports AI-based social innovations and the creation of a research centre focusing on AI to further the ecological transition.

- Enhance governments' AI expertise and use. The German strategy recognises the need to bolster the public administration's expertise in AI. The United Kingdom's AI Sector Deal commits to creating a GovTech Fund, which will support tech businesses in providing the government with innovative solutions to deliver more efficient public services.

\subsection{Target stakeholders}

The United Kingdom's AI Sector Deal, the German AI Strategy and the EU Strategy for AI target industries target public research institutions and governments. The Pan-Canadian AI Strategy also targets universities and public research institutions, although it additionally aims to promote co-operation between AI research centres and businesses.

\subsection{Main instruments}

Table 2 presents an overview of the planned actions outlined in the four AI strategies explored above. 
Table 2. Overview of instruments set in AI strategies, by objective

\begin{tabular}{|c|c|}
\hline Objective & Main instruments \\
\hline $\begin{array}{l}\text { Strengthen research } \\
\text { in } \mathrm{Al}\end{array}$ & 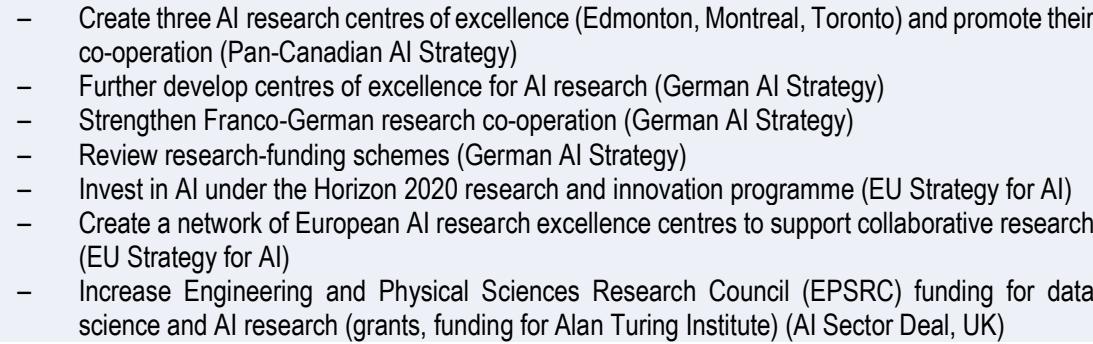 \\
\hline $\begin{array}{l}\text { Strengthen Al } \\
\text { capabilities }\end{array}$ & $\begin{array}{ll}\text { - } & \text { Al Chairs programme to attract and retain top researchers, and train young researchers (Pan- } \\
& \text { Canadian Al Strategy) } \\
\text { - } & \text { Strengthen industry-oriented PhD programmes in Al (EU Strategy for Al) } \\
\text { - } & \text { Create } 100 \text { additional professorships for Al (German Al Strategy) } \\
\text { - } & \text { Increase attractiveness of careers in public research (German Al Strategy) } \\
\text { - } & \text { Grant special visas for exceptional Al talent (Al Sector Deal, UK } \\
\text { - } & \text { Create } 200 \text { additional Al doctoral studentships (Al Sector Deal, UK) }\end{array}$ \\
\hline $\begin{array}{l}\text { Support bus } \\
\text { develop and } \\
\text { applications }\end{array}$ & $\begin{array}{ll}\text { - } & \text { Promote co-operation between Al research centres and business (Pan-Canadian AI Strategy) } \\
\text { - } & \text { Establish testing facilities to facilitate experimentation with Al technologies in real-world } \\
& \text { environments (EU Strategy for AI) } \\
\text { - } & \text { Establish regional Al clusters that promote science-industry co-operation (German AI Strategy) } \\
\text { - } & \text { Support SME access to Al (e.g. Al trainers in SME 4.0 Excellence Centres) (German Al } \\
& \text { Strategy) } \\
\text { - } & \text { Establish Al living labs and testbeds (German AI Strategy) } \\
\text { - } & \text { Launch a Tech Growth Fund Initiative (German Al Strategy) } \\
\text { - } & \text { Support application of Al in service sectors (e.g. create "Next-generation services" industrial } \\
& \text { strategy challenge) (AI Sector Deal, UK) } \\
\text { - } & \text { Integrate Al into future Industrial Strategy Challenge Fund challenges (AI Sector Deal, UK) } \\
\text { - } & \text { Support clusters (e.g. invest in Tech City UK and digital infrastructure) (Al Sector Deal, UK) }\end{array}$ \\
\hline $\begin{array}{l}\text { Deve } \\
\text { for th } \\
\text { Al }\end{array}$ & 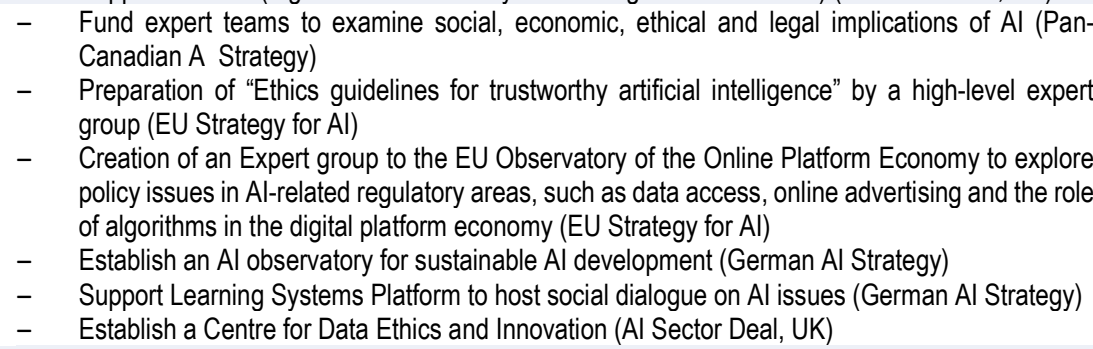 \\
\hline $\begin{array}{l}\text { Invest in } \\
\text { infrastructure }\end{array}$ & $\begin{array}{ll}\text { - } & \text { Invest in testing and experimentation infrastructures for Al products and services, building on } \\
\text { - } & \text { the network of Digital Innovation Hubs (EU Strategy for Al) } \\
\text { - } & \text { Develop super-computing infrastructure (EU Strategy for Al) } \\
\text { - } & \text { Invest in } 5 \mathrm{G} \text { mobile networks and extend full fibre broadband (AI Sector Deal, UK) }\end{array}$ \\
\hline $\begin{array}{l}\text { Support responsible } \\
\text { data access and } \\
\text { sharing }\end{array}$ & $\begin{array}{ll}\text { - } & \text { Revise the regulatory framework for the use of data and application of Al (German AI Strategy) } \\
\text { - } & \text { Launch a Support Centre for data sharing (EU Strategy for Al) } \\
\text { - } & \text { Explore new data-sharing frameworks, e.g. data trusts (AI Sector Deal, United Kingdom) } \\
\text { - } & \text { Publish more high quality public data in an open, easily findable and reusable format (AI Sector } \\
& \text { Deal, UK) }\end{array}$ \\
\hline $\begin{array}{l}\text { Support Al for } \\
\text { inclusiveness and } \\
\text { sustainable } \\
\text { development }\end{array}$ & $\begin{array}{ll}\text { - } & \text { Fund expert teams to examine social, economic, ethical and legal implications of AI (Pan- } \\
& \text { Canadian Al Strategy) } \\
\text { - } & \text { Fund Al applications to benefit the environment (German AI Strategy) } \\
\text { - } & \text { Commitment to promote diversity in the Al workforce (AI Sector Deal, UK) }\end{array}$ \\
\hline $\begin{array}{l}\text { Foster the use of } \mathrm{Al} \\
\text { by the government }\end{array}$ & $\begin{array}{ll}\text { - } & \text { Recognise the need to develop Al expertise in public administration (German AI Strategy) } \\
\text { - } & \text { Create a GovTech Fund to support innovative tech solutions for more efficient public services } \\
\text { (Al Sector Deal, UK) }\end{array}$ \\
\hline
\end{tabular}

Source: Based on Planes-Satorra and Paunov (2019[4]). 


\subsection{Critical dimensions}

- Most AI strategies focus on strengthening research in AI, and building and attracting AI talent. Both of these aspects are seen as necessary conditions to ensure future competitiveness in the field of AI. The strategies focus less on measures to support business adoption and development of AI.

- Some strategies mention the need to invest in specific infrastructures, develop responsible data-access and sharing regulations, enhance government use of AI, develop standards for the ethical use of AI and ensure that AI creates positive impacts on inclusiveness and sustainable development. However, the actions to implement these objectives are often less concrete. 


\section{Additional information}

Four of the policy initiatives covered in this report (CSIRO's Data61 in Australia, Plattform Industrie 4.0 in Austria, the Smart Industry Field Labs in the Netherlands and Digital Catapult in the United Kingdom) are explored in depth in case studies developed as part of the OECD Digital and Open Innovation project by stakeholders directly involved in the initiatives (CSIRO's Data61, 2019 ${ }_{[6]}$; Boog et al., 2019 ${ }_{[7]}$; Stolwijk and Punter, 2019 $9_{[8]}$; Digital Catapult, 2019 $\left.9_{[9]}\right)$.

The recent OECD paper "The digital innovation policy landscape in 2019" (Planes-Satorra and Paunov, 2019 ${ }_{[4]}$ ) provides a broader analysis of the current landscape of strategies and initiatives implemented in OECD countries to support innovation in the digital age. It identifies common trends and differences in national digital, smart-industry and AI strategies. The paper also discusses policy instruments used across the OECD to support digital innovation, targeting four objectives: 1) enhancing digital technology adoption and diffusion, including demonstration facilities for SMEs; 2) promoting collaborative innovation, including by creating digital-innovation clusters and knowledge intermediaries; 3) supporting research and innovation in key digital technologies, particularly AI (e.g. by establishing testbeds and regulatory sandboxes); and 4) promoting digital entrepreneurship (e.g. by supporting early-stage business acceleration).

Other useful sources that provide a theoretical framework and analysis of broader changes in innovation practices and outcomes in the digital age include the OECD report Digital Innovation: Seizing Policy Opportunities (OECD, 2019 $[10])$, and the policy papers "Innovation Policies in the Digital Age" (Guellec and Paunov, 2018 $\left.{ }_{[11]}\right)$ and "How are digital technologies changing innovation? Evidence from the agriculture, automotive and retail sectors" (Paunov and Planes-Satorra, 2019 $\left.{ }_{[12]}\right)$. 


\section{Endnotes}

${ }^{1}$ The EU Strategy for AI discussed here includes the Communication from the Commission to the European Parliament, the European Council, the Council, the European Economic and Social Committee and the Committee of the Regions on Artificial Intelligence for Europe (released in March 2018), and the associated Coordinated Plan on AI (December 2018) (European Commission, 2018 [13]; European Commission, 2018 [14]). 


\section{References}

Boog, R. et al. (2019), Case study on the Plattform Industrie 4.0, Austria: Contribution to the OECD TIP Digital and Open Innovation project, http://www.innovationpolicyplatform.org/www.innovationpolicyplatform.org/system/files/imce /PlattformIndustrie_Austria_TIPDigitalCaseStudy2019 0/index.pdf.

CSIRO's Data61 (2019), Case study on CSIRO's Data61, Australia: Contribution to the OECD TIP Digital and Open Innovation project, http://www.innovationpolicyplatform.org/www.innovationpolicyplatform.org/system/files/imce /Data61_Australia_TIPDigitalCaseStudy2019\%20(2)/index.pdf.

Digital Catapult (2019), Case study on the Digital Catapult, United Kingdom: Contribution to the OECD TIP Digital and Open Innovation project, http://www.innovationpolicyplatform.org/www.innovationpolicyplatform.org/system/files/imce /DigitalCatapult_UK_TIPDigitalCaseStudy2019_2/index.pdf.

Dutton, T., B. Barron and G. Boskovic (2018), Building an AI World: Report on National and Regional AI Strategies, CIFAR, https:/www.cifar.ca/docs/default-source/aisociety/buildinganaiworld eng.pdf?sfvrsn=fb18d129 4 (accessed on 11 February 2019).

European Commission (2018), Communication Artificial Intelligence for Europe, https:/ec.europa.eu/digital-single-market/en/news/communication-artificial-intelligence-europe (accessed on 24 June 2019).

European Commission (2018), Coordinated Plan on Artificial Intelligence, https://ec.europa.eu/digital-single-market/en/news/coordinated-plan-artificial-intelligence (accessed on 24 June 2019).

Guellec, D. and C. Paunov (2018), "Innovation policies in the digital age", OECD Science, Technology and Industry Policy Papers, No. 59, OECD Publishing, Paris, https://dx.doi.org/10.1787/eadd1094-en.

Hanson, R., A. Reeson and M. Staples (2017), Distributed Ledgers: Scenarios for the Australian economy over the coming decades, CSIRO, Canberra, https://doi.org/10.4225/08/597b89ba1a94e.

Industrie 4.0 Österreich (2018), Ergebnispapier ,Qualifikation und Kompetenzen in der Industrie 4.0“, Industrie 4.0 Österreich, https://plattformindustrie40.at/wpcontent/uploads/2018/05/WEB Industrie4.0_Ergebnispapier_2018.pdf.

OECD (2019), Digital Innovation: Seizing Policy Opportunities, OECD Publishing, Paris, https://dx.doi.org/10.1787/a298dc87-en. 
Paunov, C. and S. Planes-Satorra (2019), How are digital technologies changing innovation? Evidence from agriculture, the automotive industry and retail, No. 74, OECD Publishing, Paris, https://doi.org/10.1787/67bbcafe-en.

Planes-Satorra, S. and C. Paunov (2019), "The digital innovation policy landscape in 2019”, OECD Science, Technology and Industry Policy Papers, No. 71, OECD Publishing, Paris, https://doi.org/10.1787/6171f649-en (accessed on 1 July 2019).

Staples, M. et al. (2017), Risks and opportunities for systems using blockchain and smart contracts, CSIRO, Sydney, https://www.data61.csiro.au/ /media/052789573E9342068C5735BF604E7824.ashx.

Stolwijk, C. and M. Punter (2019), Case study on Smart Industry field labs, The Netherlands: Contribution to the OECD TIP Digital and Open Innovation project, TNO, The Hague, http://www.innovationpolicyplatform.org/www.innovationpolicyplatform.org/system/files/imce /Smart\%20industry\%20fieldlabs theNetherlands TIPDigitalCaseStudy2019 0/index.pdf. 